\title{
Mechanical Mastication of Utah Juniper Encroaching Sagebrush Steppe Increases Inorganic Soil N
}

\author{
Kert R. Young, ${ }^{1}$ Bruce A. Roundy, ${ }^{2}$ and Dennis L. Eggett ${ }^{3}$ \\ ${ }^{1}$ Jornada Experimental Range, New Mexico State University, P.O. Box 30003, MSC 3JER, Las Cruces, NM 88003-8003, USA \\ ${ }^{2}$ Department of Plant and Wildlife Sciences, Brigham Young University, Provo, UT 84602, USA \\ ${ }^{3}$ Department of Statistics, Brigham Young University, Provo, UT 84602, USA
}

Correspondence should be addressed to Kert R. Young; youngke1@msn.com

Received 20 November 2013; Revised 9 April 2014; Accepted 9 April 2014; Published 27 April 2014

Academic Editor: Davey Jones

Copyright (C) 2014 Kert R. Young et al. This is an open access article distributed under the Creative Commons Attribution License, which permits unrestricted use, distribution, and reproduction in any medium, provided the original work is properly cited.

\begin{abstract}
Juniper (Juniperus spp.) has encroached on millions of hectares of sagebrush (Artemisia spp.) steppe. Juniper mechanical mastication increases cover of understory species but could increase resource availability and subsequently invasive plant species. We quantified the effects of juniper mastication on soil resource availability by comparing total $\mathrm{C}$, total $\mathrm{N}, \mathrm{C}: \mathrm{N}$ ratio, Olsen extractable $\mathrm{P}$, sulfate $\mathrm{S}$, and $\mathrm{pH}$ using soil samples and inorganic $\mathrm{N}\left(\mathrm{NO}_{3}{ }^{-}+\mathrm{NH}_{4}{ }^{+}\right)$using ion exchange membranes. We compared resource availability in paired masticated and untreated areas in three juniper-dominated sagebrush and bunchgrass ecosystems in the Utah portion of the Great Basin. Inorganic $\mathrm{N}$ was 4.7 times higher in masticated than in untreated areas across seasons $(P<0.001)$. Within masticated areas, tree mounds of juniper leaf scales and twigs served as resource islands with 1.9 times higher inorganic $\mathrm{N}$ and total $\mathrm{C}$, and 2.8 times higher total $\mathrm{N}$ than bare interspaces across seasons $(P<0.01)$. Bare interspaces had 3.03.4 times higher inorganic $\mathrm{N}$ than interspaces covered with masticated trees during late-summer through winter $(P<0.01)$. Soil fertility changes associated with mastication were not considered sufficient to favor establishment of annual over perennial grasses, and we expect both to increase in cover following juniper mastication.
\end{abstract}

\section{Introduction}

Juniper (Juniperus spp.) trees have encroached millions of hectares of former sagebrush (Artemisia spp.) steppe in the western US. [1]. Fire historically limited dominance of these native trees over areas with limited understory cover not conducive to carrying fire but to climate change, livestock grazing in the late 1800s and early 1900s, and reduced fire frequency have contributed woodland expansion and infilling into more productive lands [1]. Juniper trees reduce understory plant cover by using soil resources that otherwise could have been used by the historic plant community. Over time, this woodland encroachment creates a more heterogeneous distribution of soil resources [2] because juniper trees move resources from interspaces between trees to subcanopy tree mounds through litter-fall (fallen foliage, twigs, and berries) and decomposition of fine roots $[3,4]$. The increased relative concentrations of soil organic matter, nutrients, and soil microorganism activity directly below trees result in resource islands $[5,6]$ that promote continued tree dominance and reduction of understory vegetation $[7,8]$ unless woodland encroachment is controlled. Land managers mechanically masticate (spinning spikes on a tractor shred/mulch standing trees) encroaching juniper trees to help restore plant community composition and reduce the potential for high-intensity crown fires and in the future may harvest trees for biofuel $[9,10]$.

The ecological concern is that masticating juniper trees could increase resource availability as has happened following juniper cutting [11]. If invasive annual weeds are abundant pretreatment, they could dominate after treatment because invasive annuals are highly responsive to soil inorganic $\mathrm{N}$, more competitive than perennials in environments with high $\mathrm{N}$ availability $[12,13]$, and more efficient at $\mathrm{N}$ uptake than native perennials $[14,15]$. In contrast, reduced soil $\mathrm{N}$ availability reduces the competitive ability of invasive 
annuals [16] more than native perennials [17, 18] reducing plant community invasibility [16]. Perennial grasses perform well with continually low soil $\mathrm{N}$ availability because they have greater root: shoot ratios for increased resource uptake in nutrient poor soils and greater nitrogen use efficiency with reallocation of nutrients from senescing leaves to new plant tissue [19].

Low soil $\mathrm{N}$ availability can be induced by adding materials with high organic $\mathrm{C}$ and low $\mathrm{N}$ content [20], which includes masticated-tree debris. Tree mastication produced debris with an average of $6413 \mathrm{~kg} \mathrm{ha}^{-1}$ (SD 4350.8) with diameters of $0-0.64 \mathrm{~cm}, 4102 \mathrm{~kg} \mathrm{ha}^{-1}$ (SD 2440) with $0.64-2.54 \mathrm{~cm}$ diameters, $1589 \mathrm{~kg} \mathrm{ha}^{-1}$ (SD 2074) with $2.54-7.62 \mathrm{~cm}$ diameters, and $391 \mathrm{~kg} \mathrm{ha}^{-1}$ (SD 1281) with $>7.62 \mathrm{~cm}$ diameters in a project that included our study locations [21]. Soil microorganisms immobilize available soil $\mathrm{N}$ when organic $\mathrm{C}$ energy sources do not provide sufficient $\mathrm{N}$ for metabolism and growth [20]. The addition of chipped Utah juniper (Juniperus osteosperma (Torr.) Little) and singleleaf piñon (Pinus monophylla Torr. and Frem.), which is similar to adding masticated tree debris, increased perennial grass density and cover and decreased invasive annual grass density and cover [22]. Benson [22] suggested that the increased perennial grass growth was associated with increased soil moisture under the wood chips and that the decreased invasive annual grass growth was associated with reduced soil $\mathrm{N}$ availability. So far, it is uncertain how much juniper tree mastication will alter plant community dynamics by altering nutrient availability, but increased soil water following juniper mastication [23] could increase diffusion of nutrients through soil solution to roots [24].

Our main objective was to determine the effect of juniper mastication on soil nutrient availability and relate this to vegetation responses in woodland treatments of previous studies. We evaluated total $\mathrm{C}$, total $\mathrm{N}, \mathrm{C}: \mathrm{N}$ ratio, Olsen extractable $\mathrm{P}$, sulfate $\mathrm{S}$, and $\mathrm{pH}$ from soil samples and inorganic $\mathrm{N}$ $\left(\mathrm{NO}_{3}{ }^{-}+\mathrm{NH}_{4}{ }^{+}\right)$from ion exchange membranes. We sought to quantify potential changes in soil nutrient availability due to the elimination of nutrient uptake by masticated trees relative to the effects of soil cover types including tree mounds and masticated-tree debris. We hypothesized that (1) juniper tree reduction by mastication will increase nutrient availability compared to untreated areas, (2) tree mounds will have higher nutrient concentrations than interspaces between tree canopies, and (3) masticated-tree debris will reduce soil $\mathrm{N}$ availability by supplying organic $\mathrm{C}$ to soil microorganisms encouraging immobilization of inorganic soil $\mathrm{N}$.

\section{Materials and Methods}

2.1. Study Locations. We measured soil nutrients at Greenville $\left(38^{\circ} 12^{\prime} \mathrm{N}, 112^{\circ} 48^{\prime} \mathrm{W}\right)$, Onaqui $\left(40^{\circ} 13^{\prime} \mathrm{N}, 112^{\circ} 28^{\prime} \mathrm{W}\right)$, and Stansbury $\left(40^{\circ} 35^{\prime} \mathrm{N}, 112^{\circ} 39^{\prime} \mathrm{W}\right)$ spread across the western Utah portion of the Great Basin, US [25, http://www.sagestep .org/]. Summers are mostly dry with most precipitation falling as snow in winter and rain during spring and fall. Annual average temperatures during the study were $9-10^{\circ} \mathrm{C}$, minimum average temperatures were $0-3^{\circ} \mathrm{C}$, and maximum average temperatures were $16-19^{\circ} \mathrm{C}$.
Greenville elevation ranges from 1,770 to $1,860 \mathrm{~m}$ with annual average precipitation of $193 \mathrm{~mm}$ in 2009 and $387 \mathrm{~mm}$ in 2010. Soils are classified as loamy-skeletal, carbonatic, and mesic Typic Calcixerepts using USDA soil taxonomy [26]. Greenville surface soil texture is gravelly sandy loam (15\% clay, $66 \%$ sand, and $19 \%$ silt), cation exchange capacity is 12.5 milliequivalents $\cdot 100$ grams $^{-1}$, and electrical conductivity is 1.0 decisiemens $\cdot$ meter $^{-1}$ (Beaver-Cove Fort soil survey). Greenville had a premastication maximum Utah juniper and two-needle piñon (Pinus edulis Engelm.) density of 586 trees $\cdot \mathrm{ha}^{-1}$ for trees taller than $0.5 \mathrm{~m}$.

Onaqui elevation ranges from 1,690 to $1,890 \mathrm{~m}$ with annual average precipitation of $259 \mathrm{~mm}$ in 2008, $287 \mathrm{~mm}$ in 2009, and $370 \mathrm{~mm}$ in 2010. Soils are classified as loamyskeletal, carbonatic, mesic, and shallow Petrocalcic Palexerolls using USDA soil taxonomy [26]. Onaqui surface soil texture is gravelly loam ( $14 \%$ clay, $45 \%$ sand, and $41 \%$ silt), cation exchange capacity is 15 milliequivalents $\cdot 100$ grams $^{-1}$, and electrical conductivity is 1.0 decisiemens $\cdot$ meter $^{-1}$ (Tooele soil survey). Onaqui had a premastication maximum Utah juniper (Juniperus osteosperma (Torr.) Little) density of 444 trees $\cdot \mathrm{ha}^{-1}$ for trees taller than $0.5 \mathrm{~m}$.

Stansbury elevation ranges from 1,710 to $1,830 \mathrm{~m}$ with annual average precipitation of $440 \mathrm{~mm}$ in 2010. Soils are classified as loamy-skeletal, mixed, active, and frigid Pachic Haploxerolls using USDA soil taxonomy [26]. Stansbury surface soil texture is very gravelly loam (14\% clay, $45 \%$ sand, and $41 \%$ silt), cation exchange capacity is 15 milliequivalents $\cdot 100$ grams $^{-1}$, and electrical conductivity is 0.0 decisiemens $\cdot$ meter $^{-1}$ (Tooele soil survey). Stansbury had a premastication maximum Utah juniper density of 1030 trees $\cdot \mathrm{ha}^{-1}$ for trees taller than $0.5 \mathrm{~m}$.

Sagebrush (Artemisia spp.) and bunchgrass plant communities previously dominated these locations but at the time of juniper tree mastication, areas to be sampled were located in dense phase III stands [sensu 1] where little understory vegetation remained. Sampled areas had less than 5\% shrub cover and less than $20 \%$ perennial grass cover. When tree encroachment was less severe, major shrubs species included Wyoming big sagebrush (Artemisia tridentata Nutt. ssp. wyomingensis Beetle \& Young), rabbitbrush (Chrysothamnus viscidiflorus (Hook.) Nutt.), and antelope bitterbrush (Purshia tridentata (Pursh) DC.). Major grass species included bluebunch wheatgrass (Pseudoroegneria spicata (Pursh) A. Löve), Sandberg bluegrass (Poa secunda J. Presl), needle and thread (Hesperostipa comata (Trin. \& Rupr.) Barkworth), Indian ricegrass (Achnatherum hymenoides (Roem. \& Schult.) Barkworth), and cheatgrass (Bromus tectorum L.).

2.2. Treatment Implementation. Trees taller than $0.5 \mathrm{~m}$ were masticated in the fall of 2006 at Onaqui and in the fall of 2007 at Greenville and Stansbury. Contractors masticated Utah juniper at Onaqui and Stansbury using a Tigercat M726E Mulcher (Tigercat Industries Inc., Brantford, ON) with Fecon Bull Hog (Fecon Inc., Lebanon, OH) masticator. A skidsteer loader with Fecon Bull Hog masticator was used to masticate Utah juniper and two-needle piñon at Greenville. These masticators masticate trees similarly. 


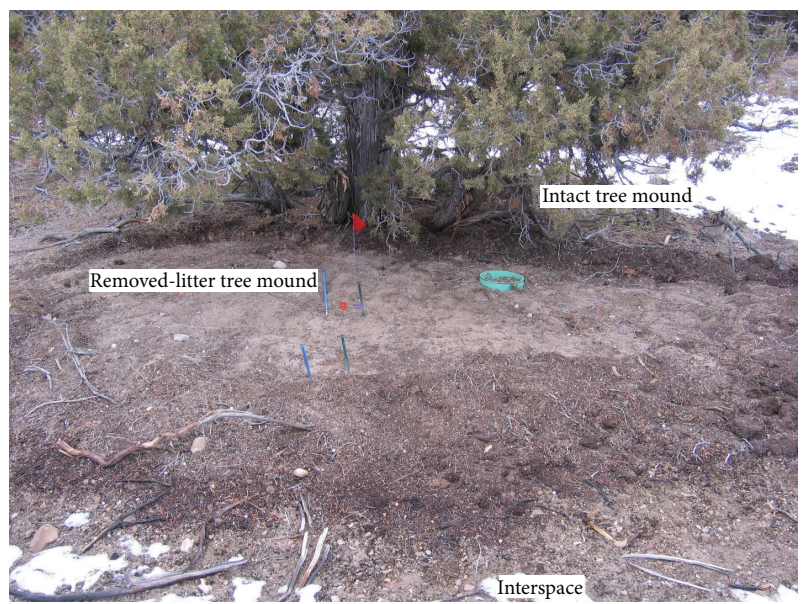

FIGURE 1: Untreated control area identifying microsite types.

2.3. Study Design. We implemented a randomized complete block design with adjacent, paired masticated, and untreated control plots to test whether mechanical mastication would increase nutrient availability, presumably by reducing juniper tree resource uptake. Untreated plots were 6-50 ha in size depending on space available for research at the three study locations. Masticated and untreated plots within a location had similar vegetation and soils. Each treatment plot had four replicated blocks and each block contained two trees. We selected trees with mounds $>2 \mathrm{~m}$ in diameter to allow enough room for sampling. We partitioned juniper interand subcanopy areas into wedge shaped microsites to separate the effects of soil cover types including tree mounds and masticated-tree debris on soil nutrient availability. In untreated plots, the area around study trees was portioned into the following three microsite types: (1) juniper tree mounds with intact litter composed of canopy-dropped leaf scales, fruits, and twigs; (2) juniper tree mounds where litter was removed by hand down to the soil surface; and (3) bare interspaces between trees with little remaining vegetation (Figure 1). In masticated plots, the areas around study trees were partitioned into the following five microsite types: (1) intact tree mounds; (2) removed-litter tree mounds; (3) bare interspaces; (4) bare interspaces covered with masticated-tree debris consisting mainly of pieces of wood, leaf scales, and bark; and (5) intact tree mounds covered by masticated-tree debris [23] (Figure 2). We combined microsite samples from replicated trees within blocks resulting in 12 samples from untreated plots and 20 samples from masticated plots for each location and sampling date.

2.4. Field Measurements. We collected microsite soil samples annually from the top $2 \mathrm{~cm}$ of the soil profile because masticated-tree debris would likely mostly influence the top portion of the soil profile where a large portion of grass roots and the active seed bank are located. Soil samples were collected during August at Greenville in 2008-2010, Onaqui in 2008-2010, and Stansbury only in 2008 due to a wildfire in August 2009 (Table 1). We analyzed soil samples for total C

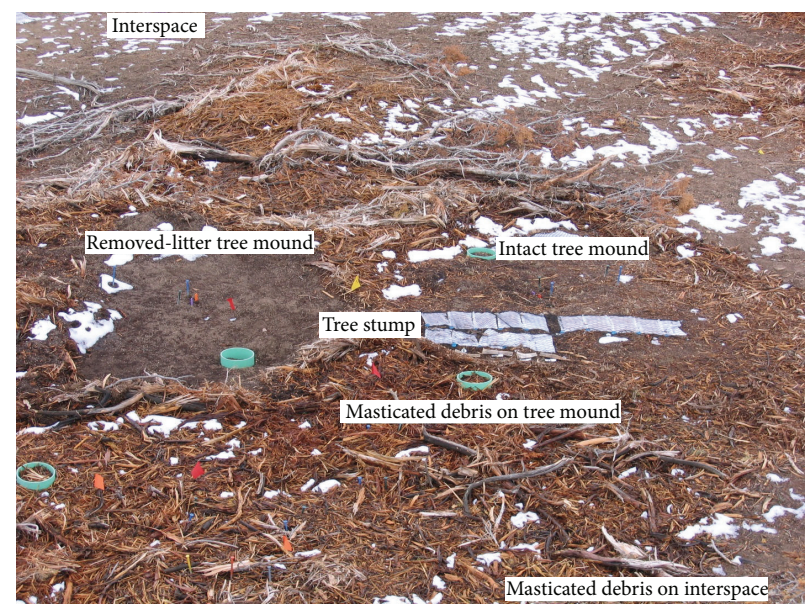

FIGURE 2: Masticated treatment area identifying microsite types.

and total N [27] using a LECO TruSpec CN analyzer (LECO Cor., St. Joseph, MI). Soil sample analyses also included Olsen $\mathrm{P}$ [28], sulfate $\mathrm{S}$ [29], and $\mathrm{pH}$ in a saturated paste [30].

We measured soil inorganic $\mathrm{N}$ that included nitrate $\left(\mathrm{NO}_{3}{ }^{-}\right)$and ammonium $\left(\mathrm{NH}_{4}{ }^{+}\right)$using plant root simulator (PRS) probes (Western Ag Innovations Inc., Saskatoon, SK) that we refer to as ion exchange membranes. Inorganic $\mathrm{N}$ measured with ion exchange membranes represents the $\mathrm{N}$ ions available to plant roots during the burial period and includes $\mathrm{N}$ that is mineralized during this time [31]. We buried ion exchange membranes vertically in the top $12 \mathrm{~cm}$ of soil in each of the 64 microsites per location where they remained for 4 months. Ion exchange membranes were replaced in March, July, and October-November to sample the seasons of winter, spring through early-summer, and late-summer through fall. We measured inorganic $\mathrm{N}$ at Greenville in 2009 and 2010, Onaqui in 2008 and 2009, and Stansbury in 2009 (Table 1). After ion exchange membranes were removed from the soil, we cleaned them with deionized water and shipped them back to Western $\mathrm{Ag}$ Innovations for colorimetric analysis of $\mathrm{NO}_{3}{ }^{-}$and $\mathrm{NH}_{4}{ }^{+}$.

2.5. Data Analysis. We analyzed response variables with mixed-model analysis of variance using Proc Mixed (SAS v9.2, SAS Institute, Inc., Cary, NC). This procedure used maximum likelihood estimation and $F$ tests to evaluate fixed effects. We applied treatments on different years in a staggerstart design [32] and analyzed years and locations together broadening our inferences beyond just one location and corresponding year. We accounted for the variance associated with some locations treated and measured on different years by nesting microsites in trees, trees in blocks, blocks in years, and years in locations in the random statement of Proc Mixed. This nested design also adjusted for potential spatial correlation across microsite types. We adjusted for potential temporal correlation using repeated measures where appropriate. The response variables of soil C: $\mathrm{N}$ ratios $(n=224)$, Olsen P $(n=64)$, sulfate S $(n=64)$, and inorganic $\mathrm{N}$ $(n=448)$ were $\log$ transformed to make variances more 
TABLE 1: Soil-sampling schedule for soil nutrients.

\begin{tabular}{|c|c|c|c|}
\hline Soil nutrient & Location & Season & Year \\
\hline Total C; total N; C:N & Greenville, Onaqui, Stansbury & Summer & 2008 \\
\hline Total C; total N; C:N & Greenville and Onaqui & Summer & 2009,2010 \\
\hline Olsen $\mathrm{P} ; \mathrm{SO}_{4}{ }^{-}-\mathrm{S} ; \mathrm{pH}$ & Greenville and Onaqui & Summer & 2010 \\
\hline Inorganic $\mathrm{N}\left(\mathrm{NO}_{3}{ }^{-}+\mathrm{NH}_{4}^{+}\right)$ & Greenville & Winter; spring-summer; summer-fall & 2009,2010 \\
\hline Inorganic $\mathrm{N}\left(\mathrm{NO}_{3}^{-}+\mathrm{NH}_{4}^{+}\right)$ & Onaqui & Winter; spring-summer; summer-fall & 2008,2009 \\
\hline Inorganic $\mathrm{N}\left(\mathrm{NO}_{3}^{-}+\mathrm{NH}_{4}^{+}\right)$ & Stansbury & Winter, Spring-Summer & 2009 \\
\hline
\end{tabular}

Soil nutrients other than inorganic $\mathrm{N}$ were analyzed from soil samples annually collected in August from the top $2 \mathrm{~cm}$ of the soil profile where the effects of masticated-tree debris were expected to be the greatest. Inorganic $\mathrm{N}$ was derived from ion exchange membranes (PRS probes) buried in the top $12 \mathrm{~cm}$ of soil. Sampling seasons for inorganic $\mathrm{N}$ were winter (November-February), spring-summer (March-June), and summer-fall (July-October).

equal prior to analysis and back-transformed to median estimates using exponentiation. Total C $(n=224)$, total $\mathrm{N}(n=224)$, and $\mathrm{pH}(n=64)$ met analysis of variance data requirements based on evaluation of residuals plots without transformation. The two additional microsite types in masticated than untreated plots prevented a full factorial analysis. To allow all treatment and microsite comparisons, we assigned each treatment by microsite combination to one of eight levels of the combined main effect of treatmentmicrosite. We evaluated the overall mastication effect by comparing the five microsite types in masticated plots with the three microsite types in untreated plots using linear contrasts. Linear contrasts also provided individual microsite comparisons within and across treatment plots. Soil inorganic $\mathrm{N}$ analysis also included the main effect of season. We used pseudo-Bonferroni with a 0.01 critical alpha level to adjust for false positives from multiple comparisons.

\section{Results}

3.1. Tree Reduction. The main effect of treatment-microsite was significant for total $\mathrm{C}$, total $\mathrm{N}, \mathrm{C}: \mathrm{N}$ ratio, Olsen $\mathrm{P}$, and sulfate $\mathrm{S}$ derived from soil samples $(P<0.05$; Table 2$)$ but masticating juniper trees that presumably reduced tree resource uptake did not alter most of these variables $(P>$ 0.01 ; Table 3 ). This indicates that most soil nutrient differences were among microsite types rather than between untreated and masticated plots $(P>0.01)$. However, the five microsite types in masticated plots together did have $7 \mathrm{mg} \mathrm{kg}^{-1}$ more $\mathrm{P}$ than the three microsite types in untreated plots $(P<0.01)$. The main and interaction effects of treatment-microsite and season were significant for inorganic $\mathrm{N}$ derived from ion exchange membranes $(P<0.01$; Table 2$)$. Juniper reduction had a greater effect on inorganic $N$ than tree mounds. The five microsite types in masticated plots together had $2.39 \mathrm{~kg} \mathrm{ha}^{-1} 4 \mathrm{mo}^{-1}$ more inorganic $\mathrm{N}$ than the three microsite types in untreated plots across all seasons $(P<0.01)$. Masticated microsites individually also had more inorganic $\mathrm{N}$ than untreated microsites $(P<0.01$; Figure 3$)$.

3.2. Soil Cover Types. Tree mounds had greater effects on soil nutrients than masticated-tree debris. Intact tree mound soils

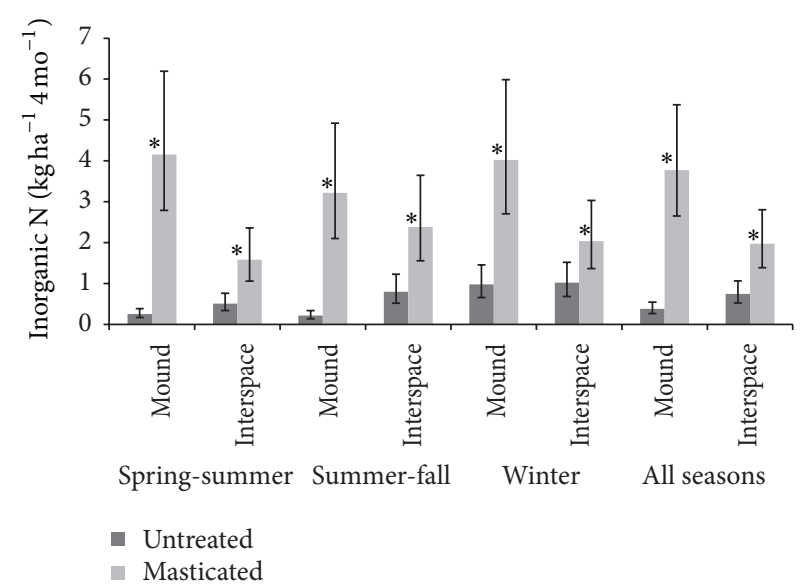

FIGURE 3: Juniper tree reduction with mechanical mastication alters inorganic $\mathrm{N}\left(\mathrm{NO}_{3}{ }^{-}+\mathrm{NH}_{4}{ }^{+}\right)$levels measured with ion exchange membranes in intact tree mounds and interspaces between trees. Asterisks indicate differences between column pairs $(P<0.01)$. Winter includes November-February, spring-summer includes March-June, and summer-fall includes July-October. Error bars are $95 \%$ confidence intervals.

had more total $\mathrm{C}$, total $\mathrm{N}$, sulfate $\mathrm{S}$, and lower $\mathrm{C}: \mathrm{N}$ ratios than bare interspaces in both masticated and untreated plots $(P<0.01$; Tables 3 and 4$)$. Tree mounds with or without intact litter and with or without masticated-tree debris in masticated plots had more inorganic $\mathrm{N}$ than interspaces with or without debris during spring-summer, winter, and all seasons together $(P<0.01$; Figures 4 and 5$)$. Litter removal from tree mounds did not change the level of most nutrients but in masticated plots it reduced Olsen $\mathrm{P}$ by $13.6 \mathrm{mg} \mathrm{kg}^{-1}$ and increased $\mathrm{pH}$ by $0.15(P<0.01$; Table 5$)$. Litter removal from tree mounds in untreated plots increased inorganic $\mathrm{N}$ by $0.35-0.43 \mathrm{~kg} \mathrm{ha}^{-1} 4 \mathrm{mo}^{-1}$ during spring-summer, summerfall, and all seasons together $(P<0.01$; Figure 4$)$. Masticatedtree debris did not alter soil nutrient levels derived from soil samples in intact tree mounds or interspaces $(P>$ 0.01; Table 4). However, masticated-tree debris decreased interspace inorganic $\mathrm{N}$ by $1.08-1.68 \mathrm{~kg} \mathrm{ha}^{-1} 4 \mathrm{mo}^{-1}$ during summer-fall, winter, and all seasons together $(P<0.01$; Figure 5). 
TABLE 2: Soil nutrient mixed-model analysis of variance and type III $F$-tests from maximum likelihood estimation.

\begin{tabular}{|c|c|c|c|c|c|}
\hline Response variables & Effect & Num $\mathrm{DF}^{1}$ & Den $\mathrm{DF}^{2}$ & $F$ value & $P$ value \\
\hline Total C\% & Treatment-microsite ${ }^{3}$ & 7 & 66 & 17.58 & $<0.001$ \\
\hline Total N\% & Treatment-microsite & 7 & 66 & 22.01 & $<0.001$ \\
\hline $\mathrm{C}: \mathrm{N}$ ratio & Treatment-microsite & 7 & 66 & 7.23 & $<0.001$ \\
\hline Olsen P mg kg${ }^{-1}$ & Treatment-microsite & 7 & 42 & 2.47 & 0.032 \\
\hline $\mathrm{SO}_{4}^{-}-\mathrm{S} \mathrm{mg} \mathrm{kg}^{-1}$ & Treatment-microsite & 7 & 42 & 6.31 & $<0.001$ \\
\hline $\mathrm{pH}$ & Treatment-microsite & 7 & 42 & 1.32 & 0.263 \\
\hline \multirow[t]{3}{*}{ Inorganic $\mathrm{N} \mathrm{kg} \mathrm{ha}{ }^{-1} 4 \mathrm{mo}^{-1}$} & Treatment-microsite & 7 & 59 & 29.71 & $<0.001$ \\
\hline & Season & 2 & 273 & 17.85 & $<0.001$ \\
\hline & Treatment-microsite $*$ season & 14 & 272 & 8.72 & $<0.001$ \\
\hline
\end{tabular}

${ }^{1}$ Num DF: numerator degrees of freedom.

${ }^{2}$ Den DF: denominator degrees of freedom.

${ }^{3}$ Treatment by microsite combinations constitute the eight levels of the treatment-microsite main effect.

TABLE 3: Tree mastication and intact tree mound effects on soil nutrients derived from soil samples.

\begin{tabular}{|c|c|c|}
\hline & Untreated & Masticated \\
\hline \multicolumn{3}{|l|}{ Total C\% } \\
\hline Tree mound intact & $6.32^{\mathrm{a}}(4.96-7.69)$ & $7.07^{\mathrm{a}}(5.71-8.43)$ \\
\hline Interspace & $3.12^{\mathrm{b}}(1.76-4.49)$ & $3.70^{\mathrm{b}}(2.34-5.07)$ \\
\hline \multicolumn{3}{|l|}{ Total N\% } \\
\hline Tree mound intact & $0.26^{\mathrm{a}}(0.21-0.32)$ & $0.28^{\mathrm{a}}(0.23-0.34)$ \\
\hline Interspace & $0.11^{\mathrm{b}}(0.06-0.17)$ & $0.10^{\mathrm{b}}(0.05-0.16)$ \\
\hline \multicolumn{3}{|l|}{$\mathrm{C}: \mathrm{N}$ ratio } \\
\hline Tree mound intact & $24.55^{\mathrm{b}}(17.11-35.24)$ & $24.95^{\mathrm{b}}(17.39-35.8)$ \\
\hline Interspace & $33.20^{\mathrm{a}}(23.14-47.66)$ & $41.12^{\mathrm{a}}(28.65-59.00)$ \\
\hline \multicolumn{3}{|l|}{ Olsen $\mathrm{P}_{\mathrm{mg} \mathrm{kg}}^{-1}$} \\
\hline Tree mound intact & $21.14^{\mathrm{a}}(15.9-28.12)$ & $33.99^{\mathrm{a}}(25.56-45.21)$ \\
\hline Interspace & $21.02^{\mathrm{a}}(15.80-27.96)$ & $22.65^{\mathrm{a}}(17.03-30.12)$ \\
\hline \multicolumn{3}{|l|}{$\mathrm{SO}_{4}^{-}-\mathrm{S} \mathrm{mg} \mathrm{kg}^{-1}$} \\
\hline Tree mound intact & $38.32^{\mathrm{a}}(13.74-106.9)$ & $31.21^{\mathrm{a}}(11.19-87.06)$ \\
\hline Interspace & $4.82^{\mathrm{b}}(1.73-13.46)$ & $8.33^{\mathrm{b}}(2.99-23.23)$ \\
\hline \multicolumn{3}{|l|}{$\mathrm{pH}$} \\
\hline Tree mound intact & $7.62^{\mathrm{a}}(7.53-7.71)$ & $7.63^{\mathrm{a}}(7.54-7.72)$ \\
\hline Interspace & $7.70^{\mathrm{a}}(7.61-7.79)$ & $7.68^{\mathrm{a}}(7.59-7.77)$ \\
\hline
\end{tabular}

No differences between columns $(P>0.01)$. Estimates with the same letter between rows are not different $(P<0.01)$. Numbers in parentheses are $95 \%$ confidence intervals.

\section{Discussion}

Tree reduction by mechanical mastication increased inorganic $\mathrm{N}$ but had no effect on soil total $\mathrm{C}$, total $\mathrm{N}, \mathrm{C}: \mathrm{N}$ ratios, sulfate $\mathrm{S}$, and $\mathrm{pH}$ and little effect on Olsen $\mathrm{P}$. Inorganic $\mathrm{N}$ was two to five times greater in masticated than untreated areas throughout the year. The increased inorganic $\mathrm{N}$ was likely due to decreased tree use of water and inorganic $\mathrm{N}$ and increased time of soil water availability $[23,33]$. Mastication of juniper trees increased the annual average number of soil wet days (>-1.5 MPa) by 27 [23]. More importantly, mastication increased the number of wet days during the growing season (spring and summer) by 44.5 [23]. Longer periods of soil water availability increase nutrient diffusion through
TABLE 4: Masticated-tree debris and intact tree mound effects on soil nutrients derived from soil samples.

\begin{tabular}{lcc}
\hline & Debris & No debris \\
\hline Total C\% & & \\
Tree mound intact & $7.61^{\mathrm{a}}(6.25-8.97)$ & $7.07^{\mathrm{a}}(5.71-8.43)$ \\
Interspace & $4.44^{\mathrm{b}}(3.08-5.80)$ & $3.70^{\mathrm{b}}(2.34-5.07)$ \\
Total N\% & & \\
Tree mound intact & $0.32^{\mathrm{a}}(0.27-0.38)$ & $0.28^{\mathrm{a}}(0.23-0.34)$ \\
Interspace & $0.16^{\mathrm{b}}(0.1-0.21)$ & $0.10^{\mathrm{b}}(0.05-0.16)$ \\
$\mathrm{C}:$ N ratio & & \\
Tree mound intact & $23.43^{\mathrm{a}}(16.33-33.62)$ & $24.95^{\mathrm{b}}(17.39-35.8)$ \\
Interspace & $31.02^{\mathrm{a}}(21.62-44.51)$ & $41.12^{\mathrm{a}}(28.65-59.00)$ \\
Olsen P mg kg ${ }^{-1}$ & & \\
Tree mound intact & $26.66^{\mathrm{a}}(20.04-35.45)$ & $33.99^{\mathrm{a}}(25.56-45.21)$ \\
Interspace & $26.02^{\mathrm{a}}(19.56-34.60)$ & $22.65^{\mathrm{a}}(17.03-30.12)$ \\
$\mathrm{SO}_{4}{ }^{-}-\mathrm{S}$ mg kg & & \\
Tree mound intact & $16.45^{\mathrm{a}}(5.90-45.88)$ & $31.21^{\mathrm{a}}(11.19-87.06)$ \\
Interspace & $3.63^{\mathrm{a}}(1.30-10.11)$ & $8.33^{\mathrm{b}}(2.99-23.23)$ \\
$\mathrm{pH}^{\text {Tree mound intact }}$ & $7.67^{\mathrm{a}}(7.58-7.76)$ & $7.63^{\mathrm{a}}(7.54-7.72)$ \\
Interspace & $7.67^{\mathrm{a}}(7.58-7.76)$ & $7.68^{\mathrm{a}}(7.59-7.77)$ \\
\hline
\end{tabular}

No differences between columns $(P>0.01)$. Estimates with the same letter between rows are not different $(P<0.01)$. Numbers in parentheses are $95 \%$ confidence intervals.

the soil solution from areas of high to low concentration, which increases adsorption of nutrients by ion exchange membranes that largely depend on nutrient diffusion [31]. The dependence of nutrient diffusion on soil water held at $>-1.5 \mathrm{MPa}$ soil water matric potentials is also critical for spring growth in sagebrush steppe $[24,33]$. These increases in resource availability in the forms of inorganic $\mathrm{N}$ and soil water result in greater annual and perennial grass production in masticated areas compared with untreated areas [34]. Mastication of juniper trees doubled to tripled bluebunch wheatgrass (native perennial) and cheatgrass (exotic invasive annual) tillers and aboveground biomass in the same areas as our study through increased resource availability [34]. 
TABLE 5: Tree mound effects on soil nutrients derived from soil samples.

\begin{tabular}{ccc}
\hline & Intact tree mound & Removed-litter tree mound \\
\hline Total C\% & & \\
Untreated & $6.32^{\mathrm{a}}(4.96-7.69)$ & $5.19^{\mathrm{a}}(3.83-6.56)$ \\
Masticated & $7.07^{\mathrm{a}}(5.71-8.43)$ & $6.23^{\mathrm{a}}(4.86-7.59)$ \\
Total N\% & & \\
Untreated & $0.26^{\mathrm{a}}(0.21-0.32)$ & $0.21^{\mathrm{a}}(0.15-0.26)$ \\
Masticated & $0.28^{\mathrm{a}}(0.23-0.34)$ & $0.24^{\mathrm{a}}(0.19-0.30)$ \\
$\mathrm{C}:$ N ratio & & \\
Untreated & $24.55^{\mathrm{b}}(17.11-35.24)$ & $25.81^{\mathrm{a}}(17.98-37.04)$ \\
Masticated & $24.95^{\mathrm{b}}(17.39-35.8)$ & $25.76^{\mathrm{a}}(17.95-36.97)$ \\
Olsen P mg kg & & \\
Untreated & $21.14^{\mathrm{a}}(15.9-28.12)$ & $14.65^{\mathrm{a}}(11.01-19.48)$ \\
Masticated & $33.99^{\mathrm{a}}(25.56-45.21)$ & $20.39^{\mathrm{b}}(15.33-27.12)$ \\
$\mathrm{SO}_{4}^{-}-$-S mg kg & & \\
Untreated & $38.32^{\mathrm{a}}(13.74-106.9)$ & $30.92^{\mathrm{a}}(11.08-86.26)$ \\
Masticated & $31.21^{\mathrm{a}}(11.19-87.06)$ & $12.54^{\mathrm{a}}(4.5-34.99)$ \\
$\mathrm{pH}^{-1}$ & \\
Untreated & $7.62^{\mathrm{a}}(7.53-7.71)$ & $7.70^{\mathrm{a}}(7.61-7.78)$ \\
Masticated & $7.63^{\mathrm{a}}(7.54-7.72)$ & $7.78^{\mathrm{a}}(7.69-7.87)$ \\
\hline
\end{tabular}

Estimates with the same letter between columns are not different $(P<0.01)$. Numbers in parentheses are $95 \%$ confidence intervals.

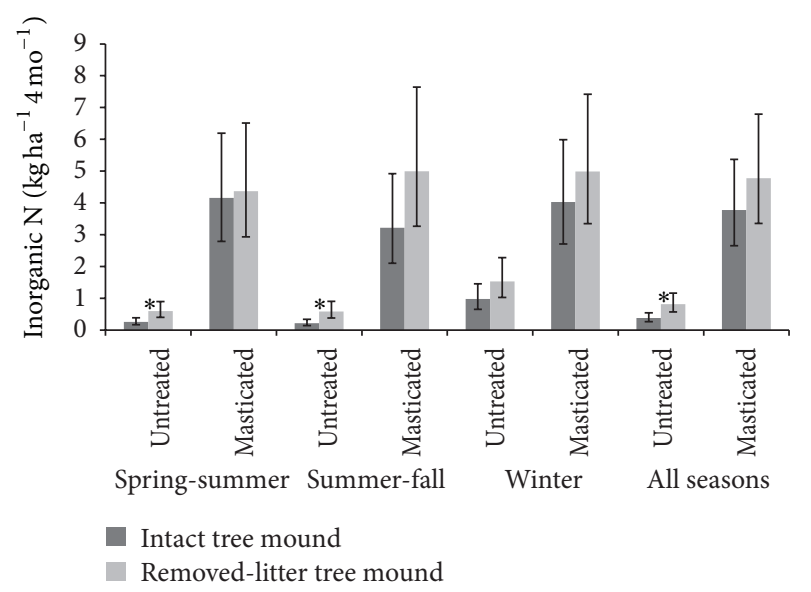

FIgure 4: Tree mound effects on inorganic $\mathrm{N}\left(\mathrm{NO}_{3}{ }^{-}+\mathrm{NH}_{4}{ }^{+}\right)$ derived from ion exchange membranes. Asterisks indicate differences between column pairs $(P<0.01)$. Winter includes November-February, spring-summer includes March-June, and summer-fall includes July-October. Error bars are 95\% confidence intervals.

The lack of tree reduction effect on soil total C, total N, sulfate $\mathrm{S}$, and $\mathrm{pH}$ was likely a result of slow plant material decomposition. Slow decomposition of juniper is expected due to the aridity of the environment, the high $\mathrm{C}: \mathrm{N}$ ratio of the woody debris, and limited incorporation of debris into the soil [20]. Future sampling is needed to determine longterm decomposition effects on soil nutrient concentrations. Techniques to better incorporate masticated-tree debris into the soil could increase total soil $\mathrm{C}$ in the short term as has

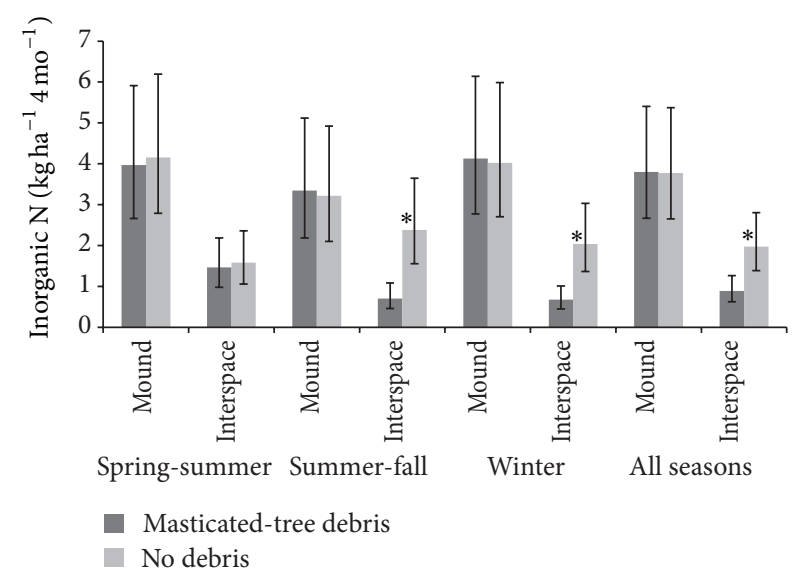

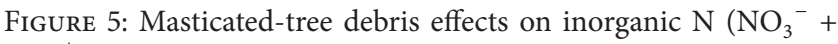
$\mathrm{NH}_{4}^{+}$) derived from ion exchange membranes in intact tree mounds and interspaces between trees. Asterisks indicate differences between column pairs $(P<0.01)$. Winter includes November-February, spring-summer includes March-June, and summer-fall includes July-October. Error bars are 95\% confidence intervals.

been found with sawdust [35]. Lyons and McCarthy [36] found a mass-loss decay constant of $0.176 \mathrm{yr}^{-1}$ based on annual mass loss of Ashe juniper (Juniperus ashei J. Buchholz) wood 2 years after chipping on the Edwards Plateau in Texas. Our locations are expected to have slower decomposition rates with $10^{\circ} \mathrm{C}$ cooler annual average temperatures and half the annual average precipitation of Edwards Plateau [23, 36].

Tree mounds with and without masticated-tree debris had higher concentrations of total C, total N, and inorganic $\mathrm{N}$ than adjacent interspaces with or without debris cover. High soil fertility in juniper mounds compared to interspaces is a well-known phenomenon [3, 4, 6, 37]. Juniper trees develop these resource islands as their roots mine resources from interspaces and drop nutrients under their canopies in the form of leaf scales, fruits, and twigs over decades [3-5]. The redistribution of nutrients and increasing size of resource islands during woody plant encroachment may serve as a positive feedback mechanism $[8,38]$. This feedback may encourage the continued dominance of woody plants as soil and nutrients are lost from the interspaces through wind and water erosion further increasing desertification $[8,38]$. This process makes it more difficult for the former distribution of resources and preencroachment plant community to return after disturbance $[8,38]$.

High levels of inorganic $\mathrm{N}$ after mastication could favor invasive annuals over native perennials. Increased soil $\mathrm{N}$ has been shown to increase aboveground tissue $\mathrm{N}$ concentrations, growth rates, and competitive ability of annual grasses as well as to encourage dominance of invasive annuals over perennials $[19,39-43]$. This potential increase in invasive annuals would most likely occur in intact tree mounds where soil $\mathrm{N}$ availability is abundant and where the duration of available soil water is high following tree reduction [23]. However, higher inorganic $\mathrm{N}$ did not result in a general increase in seedling establishment of sown annual or perennial grasses in 
intact tree mounds compared to interspaces in an associated study [34]. This may be due to reduced light penetration and seedling emergence under litter [44] or because soil $\mathrm{N}$ availability may have been sufficient for plant growth even in interspaces. This suggests that juniper mastication will not favor invasive annuals more or less than native perennials.

Even though resource islands do eventually dissipate with time since tree reduction [8], many years are required. Resource islands can last for 15 years after juniper cutting as a result of deep tree mounds [45]. As nutrient concentrations in old tree mounds degrade over time, resource islands become smaller, nutrients become more evenly distributed, and resilience of the preencroachment plant community may be strengthened $[8,46]$. Restoring the appropriate scale of resource patchiness through anthropogenic means or fire has been suggested as an important step in the reestablishment of preencroachment plant communities [8, 46, 47]. A more rapid return of preencroachment sized resource islands and distribution is especially important in these systems because invasive annuals or surviving trees will likely dominate before resource islands naturally dissipate where perennial grasses and shrubs are absent. More research is needed to fully understand the potential for mechanical or fire manipulation of the size of resource patches to encourage reestablishment of the preencroachment plant community.

Higher inorganic $\mathrm{N}$ in tree mounds than interspaces with or without debris in masticated plots illustrates the resource island distribution pattern. However, intact tree mounds had less inorganic $\mathrm{N}$ than removed-litter tree mounds and interspaces in untreated plots. Ion exchange membranes in tree mounds may have adsorbed less $\mathrm{N}$ than in interspaces of untreated plots because of more intense competition for soil $\mathrm{N}$ from a higher concentration of juniper fine feeder roots in tree mounds than in interspaces [48]. The higher inorganic $\mathrm{N}$ in removed-litter tree mounds and interspaces than intact tree mounds in untreated plots may also have been due to warmer soil temperatures. Removed-litter tree mounds had 224 more degree days $\left(>0^{\circ} \mathrm{C}\right)$ and interspaces had 382 more degree days than intact tree mounds during spring and summer [23]. High soil temperatures can reduce juniper root activity [49] and thereby reduce competition for soil $\mathrm{N}$ near the surface allowing more $\mathrm{N}$ ions to be adsorbed by ion exchange membranes in removed-litter tree mounds and interspaces.

Microsites in masticated plots collectively had more Olsen $\mathrm{P}$ than microsites in untreated plots. This result may have been due to reduced $\mathrm{P}$ uptake by trees after mechanical mastication, longer durations of plant available water [23] allowing more $\mathrm{P}$ mineralization during spring, or $\mathrm{P}$ being released into the soil solution through microorganism mineralization of organic P from decomposing roots [20]. Within masticated plots, intact tree mounds had more $\mathrm{P}$ than removed-litter tree mounds. This result may have been due to the longer durations of plant available soil water in intact tree mounds with 28 more wet days during spring than removed-litter tree mounds in masticated plots [23]. As low $\mathrm{P}$ availability has been suggested as a limiting factor of plant growth in juniper woodlands [50-52], the slight increase in $\mathrm{P}$ after juniper mastication may lead to increased plant production as with bluebunch wheatgrass and cheatgrass discussed earlier [34]. Plants that currently occupy the site are more likely to benefit from the increased $\mathrm{P}$ availability than plants that require time to propagate into treated areas because $\mathrm{P}$ can quickly react with calcium in alkaline soils and become less available in the form of calcium phosphate [20]. This emphasizes the importance of preventing initial juniper tree or weedy species dominance because the composition of the pretreatment plant community largely determines the posttreatment plant community [53].

Inorganic $\mathrm{N}$ levels were similar between bare and debriscovered interspaces during spring, a critical season for seedling establishment, even though debris-covered interspaces had less inorganic $\mathrm{N}$ during late-summer through winter. We had expected woody masticated-tree debris with a high $\mathrm{C}: \mathrm{N}$ ratio to lower inorganic $\mathrm{N}$ in debris-covered interspaces because soil microorganisms need organic $\mathrm{C}$ sources with $\mathrm{C}: \mathrm{N}$ ratios not higher than $25: 1$ for metabolism [20]. Otherwise, they use available soil $\mathrm{N}$ to support their decomposition of high $\mathrm{C}: \mathrm{N}$ ratio plant material [20]. Western juniper (Juniperus occidentalis Hook.), a species similar to Utah juniper, has wood C: $\mathrm{N}$ ratios of $240: 1$ [54]. If woody masticated-tree debris had lowered inorganic $\mathrm{N}$ during spring, then we would have expected a negative effect on invasive annual seedlings compared to perennial grass seedlings. Lower successional, invasive annuals tend to be replaced by more competitive perennial species over successional time as nutrient availability decreases, even though the annuals generally grow rapidly under conditions of high resource availability after disturbance $[55,56]$. Cheatgrass, for example, increased in cover mostly where soil water and nutrient availability were expected to be greatest due to the least amount of competing vegetation [57]. When continually low soil $\mathrm{N}$ availability is maintained for several years, reductions in the growth, tillering, and seed production of invasive annuals like cheatgrass may allow dominance of established perennials over semiarid lands [19, 43, 58]. In addition, reductions in soil $\mathrm{N}$ availability are thought to reduce the invasibility of plant communities [16] and thereby strengthen the resistance and resilience of preencroachment plant communities to invasive annuals. Treated areas are likely to be dominated by perennials after juniper reduction even where juniper encroachment was high as long as invasive annual plant cover is limited and perennial plants remain after treatment [57]. A survey of masticated sites across Utah found that, when perennial herbaceous cover was $>30 \%$, cheatgrass cover was usually $<10 \%$ [59] because abundant perennial grass limits cheatgrass dominance [53, 60-63].

4.1. Implications. Juniper trees are masticated to reduce the danger of crown fire and to restore the historic sagebrush steppe plant community. Our soil nutrient comparisons reflect not only the results of juniper tree mastication but also the potential effects of juniper tree removal for biofuel production in areas that did not receive masticated-tree debris. Mastication improves growing conditions for plants by increasing inorganic $\mathrm{N}$ in this $\mathrm{N}$ limited system. The abundance of residual perennial species compared to the abundance and propagule pressure of invasive annual species 
will greatly affect which life form benefits most from the increased resource availability following tree reduction [13, $62,64,65]$. Whether invasive annuals or perennials dominate long-term given increased resource availability following juniper mastication remains to be seen. Mechanical mastication of juniper may provide an opportunity to not only reduce juniper encroachment but also mechanically spread tree mounds. This should hasten the redistribution of nutrients back to a pretree encroached distribution of resources more characteristic of the sagebrush steppe. Restoring predisturbance resource distribution aids in the restoration of historic plant communities [8, 46, 47]. Monitoring of restoration projects will play an important role in assessing the longterm impacts of juniper mastication on resource availability and plant community dynamics. Maintenance of vigorous and diverse preencroachment vegetation should limit the resources available to invasive annuals and may be the most effective form of weed control $[12,60]$. Hence, it is imperative to masticate trees when desirable perennials are still abundant enough to use the increased resource availability following juniper reduction and limit niches of resource availability to invasive annuals.

\section{Conflict of Interests}

The authors declare that there is no conflict of interests regarding the publication of this paper.

\section{Acknowledgments}

The authors thank the USDI Bureau of Land Management and USDA Forest Service in Utah for allowing this research on public lands. They are grateful to the research site managers, April Hulet and Brad Jessop, and the several students that helped with field work. The authors thank the reviewers for constructive comments that helped improve the content of this paper. This is contribution number 70 of the Sagebrush Steppe Treatment Evaluation Project (SageSTEP) funded by the US Joint Fire Science Program, the Bureau of Land Management, and the National Interagency Fire Center.

\section{References}

[1] R. F. Miller, J. D. Bates, T. J. Svejcar, F. B. Pierson, and L. E. Eddleman, Biology, Ecology, and Management of Western Juniper, Technical Bulletin no. 152, Oregon State University Agricultural Experiment Station, Corvallis, Ore, USA, 2005.

[2] S. R. Archer, K. W. Davies, T. E. Fulbright, K. C. McDaniel, B. P. Wilcox, and K. I. Predick, "Brush management as a rangeland conservation strategy: a critical evaluation," in Conservation Benefits of Rangeland Practices: Assessment, Recommendations, and Knowledge Gaps, D. D. Briske, Ed., pp. 105-170, USDA Natural Resources Conservation Service, Urbandale, Iowa, USA, 2011.

[3] P. A. McDaniel and R. C. Graham, "Organic carbon distributions in shallow soils of pinyon-juniper woodlands," Soil Science Society of America Journal, vol. 56, no. 2, pp. 499-504, 1992.

[4] D. W. Davenport, B. P. Wilcox, and D. D. Breshears, "Soil morphology of canopy and intercanopy sites in a Piñon-Juniper woodland," Soil Science Society of America Journal, vol. 60, no. 6, pp. 1881-1887, 1996.

[5] J. M. Klopatek, "Nitrogen mineralization and nitrification in mineral soils of pinyon- juniper ecosystems," Soil Science Society of America Journal, vol. 51, no. 2, pp. 453-457, 1987.

[6] S. Krämer and D. M. Green, "Phosphorus pools in tree and intercanopy microsites of a juniper-grass ecosystem," Soil Science Society of America Journal, vol. 63, no. 6, pp. 1901-1905, 1999.

[7] P. S. Doescher, L. E. Eddleman, and M. R. Vaitkus, "Evaluation of soil nutrients, $\mathrm{pH}$, and organic matter in rangelands dominated by western juniper," Northwest Science, vol. 61, no. 2, pp. 97-102, 1987.

[8] W. H. Schlesinger and A. M. Pilmanis, "Plant-soil interactions in deserts," Biogeochemistry, vol. 42, no. 1-2, pp. 169-187, 1998.

[9] W. K. Jaeger, R. Cross, and T. M. Egelkraut, Biofuel Potential in Oregon: Background and Evaluation of Options, Special Report 1078, Oregon State University Extension Service, Corvallis, Ore, USA, 2007.

[10] K. E. Skog, R. Rummer, B. Jenkins et al., "A strategic assessment of biofuels development in the western states," in Forest Inventory and Analysis (FIA) Symposium 2008, W. McWilliams, G. Moisen, and R. Czaplewski, Eds., Proceedings RMRS-P-56CD, USDA Forest Service, Rocky Mountain Research Station, Fort Collins, Colo, USA, 2009.

[11] J. D. Bates, R. F. Miller, and T. J. Svejcar, "Understory dynamics in cut and uncut western juniper woodlands," Journal of Range Management, vol. 53, no. 1, pp. 119-126, 2000.

[12] E. Vasquez, R. Sheley, and T. Svejcar, "Creating invasion resistant soils via nitrogen management," Invasive Plant Science and Management, vol. 1, no. 3, pp. 304-314, 2008.

[13] M. B. Mazzola, J. C. Chambers, R. R. Blank et al., "Effects of resource availability and propagule supply on native species recruitment in sagebrush ecosystems invaded by Bromus tectorum," Biological Invasions, vol. 13, no. 2, pp. 513-526, 2011.

[14] R. E. Eckert Jr. and R. A. Evans, "Responses of downy brome and crested wheatgrass to nitrogen and phosphorous in nutrient solution," Weeds, vol. 11, pp. 170-174, 1963.

[15] J. A. Young and C. D. Clements, Cheatgrass: Fire and Forage on the Range, University of Nevada Press, Reno, Nev, USA, 2009.

[16] J. Beckstead and C. K. Augspurger, "An experimental test of resistance to cheatgrass invasion: limiting resources at different life stages," Biological Invasions, vol. 6, no. 4, pp. 417-432, 2004.

[17] G. J. Herron, R. L. Sheley, B. D. Maxwell, and J. S. Jacobsen, "Influence of nutrient availability on the interaction between spotted knapweed and bluebunch wheatgrass," Restoration Ecology, vol. 9, no. 3, pp. 326-331, 2001.

[18] J. Krueger-Mangold, R. Sheley, and R. Engel, "Can R*s predict invasion in semi-arid grasslands?" Biological Invasions, vol. 8, no. 6, pp. 1343-1354, 2006.

[19] T. A. Monaco, D. A. Johnson, J. M. Norton et al., "Contrasting responses of intermountain west grasses to soil nitrogen," Journal of Range Management, vol. 56, no. 3, pp. 282-290, 2003.

[20] N. C. Brady and R. R. Weil, The Nature and Properties of Soils, Prentice-Hall, Upper Saddle River, NJ, USA, 12th edition, 1999.

[21] K. R. Young, B. A. Roundy, S. C. Bunting, and D. L. Eggett, "Utah juniper andtwo-needle piñon reduction alters fuel loads," International Journal of Wildland Fire. In press.

[22] T. L. Benson, Understory vegetation responses to pinyon-juniper tree removal, seeding, and chip application, Lincoln County, Nevada [M.S. thesis], University of Nevada, Reno, Nev, USA, 2006. 
[23] K. R. Young, B. A. Roundy, and D. L. Eggett, "Tree reduction and debris effects of mastication on soil climate variables in Utah juniper woodlands," Forest Ecology and Management, vol. 310, pp. 777-785, 2013.

[24] A. J. Leffler and R. J. Ryel, "Resource pool dynamics: conditions that regulate species interactions and dominance," in Invasive Plant Ecology and Management: Linking Processes to Practice, T. A. Monaco and R. L. Sheley, Eds., pp. 57-78, CABI, Cambridge, Mass, USA, 2012.

[25] J. D. McIver, M. Brunson, and S. C. Bunting, "The sagebrush steppe treatment evaluation project (SageSTEP): a test of state-and-transition theory," Tech. Rep. RMRS-GTR-237, USDA Forest Service, Rocky Mountain Research Station, Fort Collins, Colo, USA, 2010.

[26] B. M. Rau, D. W. Johnson, R. R. Blank et al., "Woodland expansion's influence on belowground carbon and nitrogen in the Great Basin U.S," Journal of Arid Environments, vol. 75, no. 9, pp. 827-835, 2011.

[27] S. L. McGeehan and D. V. Naylor, "Automated instrumental analysis of carbon and nitrogen in plant and soil samples," Communications in Soil Science \& Plant Analysis, vol. 19, no. 4, pp. 493-505, 1988.

[28] S. R. Olsen, C. V. Cole, F. S. Watanabe, and L. A. Dean, Estimation of Available Phosphorus in Soil by Extraction with Sodium Bicarbonate, Circular no. 939, USDA Government Printing Office, Washington, DC, USA, 1954.

[29] C. H. Williams and A. Steinbergs, "The evaluation of plantavailable sulphur in soils. II. The availability of adsorbed and insoluble sulphates," Plant and Soil, vol. 21, no. 1, pp. 50-62, 1964.

[30] J. D. Rhodes, "Soluble salts," in Methods of Soil Analysis: Part 2, A. L. Page, Ed., pp. 167-179, American Society of Agronomy, Madison, Wis, USA, 1982.

[31] P. Qian and J. J. Schoenau, "Practical applications of ion exchange resins in agricultural and environmental soil research," Canadian Journal of Soil Science, vol. 82, no. 1, pp. 9-21, 2002.

[32] T. M. Loughin, "Improved experimental design and analysis for long-term experiments," Crop Science, vol. 46, no. 6, pp. 24922502, 2006.

[33] B. A. Roundy, K. R. Young, N. Cline et al., "Piñon-juniper reduction effects on soil temperature and water availability of the resource growth pool," Rangeland Ecology \& Management. In press.

[34] K. R. Young, B. A. Roundy, and D. L. Eggett, "Plant establishment in masticated Utah juniper woodlands," Rangeland Ecology \& Management, vol. 66, pp. 597-607, 2013.

[35] S. G. Baer, J. M. Blair, S. L. Collins, and A. K. Knapp, "Soil resources regulate productivity and diversity in newly established tallgrass prairie," Ecology, vol. 84, no. 3, pp. 724-735, 2003.

[36] K. G. Lyons and W. A. McCarthy, "Early decomposition of Ashe juniper (Juniperus ashei) wood in open and shaded habitat," Rangeland Ecology \& Management, vol. 63, pp. 359-365, 2010.

[37] J. D. Brotherson and S. T. Osayande, "Mineral concentrations in true mountain mahogany and Utah juniper, and in associated soils," Journal of Range Management, vol. 33, pp. 182-185, 1980.

[38] W. H. Schlesinger, J. F. Reynolds, G. L. Cunningham et al., "Biological feedbacks in global desertification," Science, vol. 247, no. 4946, pp. 1043-1048, 1990.

[39] F. A. Bazzaz, "The physiological ecology of plant succession," Annual Review of Ecology, Evolution, and Systematics, vol. 10, pp. 351-371, 1979.
[40] D. Tilman, Resource Competition and Community Structure, Princeton University Press, Princeton, NJ, USA, 1982.

[41] D. Tilman, "Secondary succession and the pattern of plant dominance along experimental nitrogen gradients," Ecological Monographs, vol. 57, no. 3, pp. 189-214, 1987.

[42] T. McLendon and E. F. Redente, "Effects of nitrogen limitation on species replacement dynamics during early secondary succession on a semiarid sagebrush site," Oecologia, vol. 91, no. 3, pp. 312-317, 1992.

[43] M. W. Paschke, T. McLendon, and E. F. Redente, "Nitrogen availability and old-field succession in a shortgrass steppe," Ecosystems, vol. 3, no. 2, pp. 144-158, 2000.

[44] J. M. Facelli and S. T. A. Pickett, "Plant litter: its dynamics and effects on plant community structure," Botanical Review, vol. 57, no. 1, pp. 1-32, 1991.

[45] C. T. Miwa and R. J. Reuter, "Persistence of western juniper (Juniperus occidentalis) resource islands following canopy removal," Northwest Science, vol. 84, no. 4, pp. 361-368, 2010.

[46] S. Ravi, P. D’Odorico, L. Wang et al., "Post-fire resource redistribution in desert grasslands: a possible negative feedback on land degradation," Ecosystems, vol. 12, no. 3, pp. 434-444, 2009.

[47] B. Boeken and M. Shachak, "Desert plant communities in human-made patches-implications for management," Ecological Applications, vol. 4, no. 4, pp. 702-716, 1994.

[48] R. Everett, S. Sharrow, and D. Thran, "Soil nutrient distribution under and adjacent to singleleaf pinyon crowns," Soil Science Society of America Journal, vol. 50, no. 3, pp. 788-792, 1986.

[49] D. G. Williams and J. R. Ehleringer, "Intra- and interspecific variation for summer precipitation use in pinyon-juniper woodlands," Ecological Monographs, vol. 70, no. 4, pp. 517-537, 2000.

[50] E. D. Bunderson, D. J. Weber, and J. N. Davis, "Soil mineral composition and nutrient uptake in Juniperus osteosperma in 17 Utah sites," Soil Science, vol. 139, no. 2, pp. 139-148, 1985.

[51] A. R. Tiedemann, "Nutrient accumulations in pinyon-juniper ecosystems-managing for future site productivity," in PinyonJuniper Conference Proceedings, Reno, Nevada, January 13-16, 1986, R. L. Everett, Ed., INT-GTR-215, pp. 352-359, USDA Forest Service, Intermountain Research Station, Ogden, Utah, USA, 1987.

[52] S. Krämer and D. M. Green, "Acid and alkaline phosphatase dynamics and their relationship to soil microclimate in a semiarid woodland," Soil Biology and Biochemistry, vol. 32, no. 2, pp. 179-188, 2000.

[53] R. F. Miller, J. Ratchford, B. A. Roundy et al., "Response of conifer encroached shrublands in the Great Basin to prescribed fire and mechanical treatments," Rangeland Ecology \& Management. In press.

[54] J. D. Bates, T. J. Svejcar, and R. F. Miller, "Effects of juniper cutting on nitrogen mineralization," Journal of Arid Environments, vol. 51, no. 2, pp. 221-234, 2002.

[55] J. P. Grime and R. Hunt, "Relative growth-rate: its range and adaptive significance in a local flora," Journal of Ecology, vol. 63, pp. 393-422, 1975.

[56] D. Tilman, "Community diversity and succession: the roles of competition, dispersal, and habitat modification," in Biodiversity and Ecosystem Function, E. D. Schulze and H. A. Mooney, Eds., pp. 327-344, Springer, New York, NY, USA, 1993.

[57] B. A. Roundy, R. F. Miller, R. J. Tausch et al., "Understory cover responses to piñon-juniper treatments across tree dominance gradients in the Great Basin," Rangeland Ecology \& Management. In press. 
[58] E. F. Redente, J. E. Friedlander, and T. McLendon, "Response of early and late semiarid seral species to nitrogen and phosphorus gradients," Plant and Soil, vol. 140, no. 1, pp. 127-135, 1992.

[59] J. Bybee, Understory vegetation response to mechanical mastication of piñon and juniper woodlands [M.S. thesis], Brigham Young University, Provo, Utah, USA, 2013.

[60] J. C. Chambers, B. A. Roundy, R. R. Blank, S. E. Meyer, and A. Whittaker, "What makes Great Basin sagebrush ecosystems invasible by Bromus tectorum?" Ecological Monographs, vol. 77, no. 1, pp. 117-145, 2007.

[61] J. C. Chambers, R. F. Miller, D. I. Board et al., "Resilience and resistance of sagebrush ecosystems: implications for state and transition models and management treatments," Rangeland Ecology \& Management. In press.

[62] J. D. Bates, R. F. Miller, and T. Svejcar, "Long-term successional trends following western juniper cutting," Rangeland Ecology \& Management, vol. 58, no. 5, pp. 533-541, 2005.

[63] J. D. Bates, K. W. Davies, and R. N. Sharp, "Shrub-steppe early succession following juniper cutting and prescribed fire," Environmental Management, vol. 47, no. 3, pp. 468-481, 2011.

[64] R. F. Miller and P. E. Wigand, "Holocene changes in semiarid pinyon-juniper woodlands. Response to climate, fire, and human activities in the US Great Basin," BioScience, vol. 44, no. 7, pp. 465-474, 1994.

[65] B. L. Foster and T. L. Dickson, "Grassland diversity and productivity: the interplay of resource availability and propagule pools," Ecology, vol. 85, no. 6, pp. 1541-1547, 2004. 

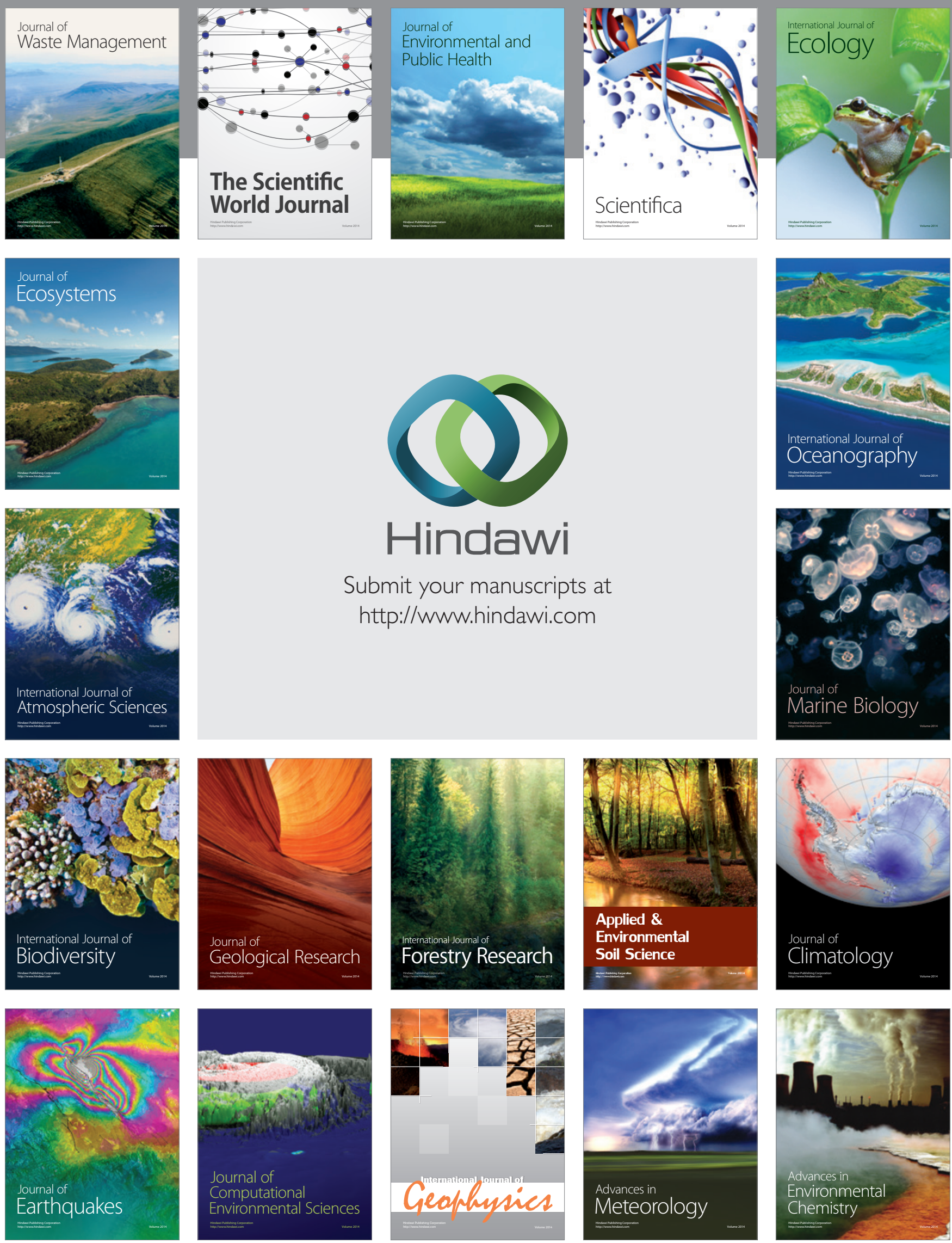